\title{
THE EFFECT OF ANEUPLOIDY UPON THE PROGENY OF AN AUTOTETRAPLOID RIBES NIGRUM
}

\author{
Antero VaARama \\ State Horticultural Institute, Piikkiö, Finland
}

Received 16th March 1953

The phenotypic effect of aneuploidy, i.e., the effect upon the development of an organism of a genome which is either devoid of a few chromosomes or has a few in excess, has been intensively investigated in several plant species. The results of investigations conducted with different types of trisomic plants in the genus Datura are classical $(1,2)$, as well as those on monosomic types in the genus Nicotiana (3), and on nullosomics in the common wheat (8).

The strength of the effect of either a deficiency or an excess of one or a few chromosomes in a plant species depends on the type of its genome. In general the effect is most striking in diploid or strongly diploidized species. Further the effect is, as a rule, clearly discernible in amphidiploids (9); sometimes, as in amphidiploids of the genus Gossypium, to such a extent that it is impossible to produce any monosomic individuals at all (11). The strength of the effect decreases with increase in the genotypic similarities between the parent species of an amphidiploid. This state of affairs has been observed in the investigation of the progeny of Dactylis glomerata performed by MünTZING (6). In this study D. glomerata is considered to be an autotetraploid, whereas STEBBins (10) suggests that it is an amphidiploid formed from two closely related species. The effect of aneuploidy is clearly indicated by statistical treatment of quantitative measurements.

$A$ priori it is to be expected that the effect of aneuploidy would be least in the chromosome number variants of a progeny raised from an autotetraploid, especially from a newly induced one. In such a case every gene is present in quadruple state, and every gain or loss of a gene may be expected to cause merely quantitative changes in the genotype.

Furthermore, it is clear that the effect of aneuploidy diminishes with increasing degree of polyploidy. It is a well known fact that the chromosome number may vary in a highly polyploid plant species without any clearly discernible phenotypic effect. 
In the literature there are only a few observations concerning the characteristics of aneuploid types in the progenies of artificial polyploids. The following observations relating to the species Ribes nigrum are intended as a contribution to our knowledge of this problem.

\section{Material}

The material studied consisted of a $\mathrm{C}_{2}$ progeny raised from seed obtained from a $\mathrm{C}_{1}$ plant of tetraploid Ribes nigrum produced by colchicine treatment. This mother plant has been described morphologically as well as cytologically in an earlier paper (12). The original number of $\mathrm{C}_{2}$ plants grown at the Experimental Garden of the State Horticultural Institute, Piikkiö, Finland, was 174, but it was possible to determine the chromosome number of only 139 of them. These plants comprise the material used in this investigation. Some variation in the somatic chromosome number was observed in the material studied (14). In addition to individuals that were even tetraploids with $2 n=32$, a number of plants with 30 , $31,33,34$, and 35 somatic chromosomes were encountered. The plants with 30 and 35 chromosomes, however, perished at a very early stage of development. Furthermore, there were detected among the progeny studied three plants with a diploid, $2 n=16$, chromosome number (14), a phenomenon which seems to be rather common among the progenies of artificial tetraploids $(7)$.

The plants were subject to continuous observation covering a number of characteristics during their growth at the Experimental Garden. The records made have been subjected to statistical treatment, and the different chromosome classes have been compared with each other.

\section{Observations}

The frequency of Ribes nigrum plants belonging to different chromosome classes is presented in table 1.

Table 1. Actual and expected frequency of individuals in different chromosome classes.

$$
2 n=16 \quad 2 n=30 \quad 2 n=31 \quad 2 n=32 \quad 2 n=33 \quad 2 n=34 \quad 2 n=35
$$

\begin{tabular}{lrrrrrrr}
\hline Actual frequency & 3 & 1 & 16 & 85 & 21 & 12 & 1 \\
Expected frequency & - & 84 & 98 & 85 & 36 & 5 & - \\
\hline
\end{tabular}

The expected sizes of different chromosome classes have been calculated on the basis of earlier knowledge of the percentage of different chromosome classes among the pollen grains of the $\mathrm{C}_{1}$ plant $\mathrm{B}$, the mother plant of the progeny investigated. The observed (12) percentages were: $n=13(4 \%), n=14(16 \%), n=15$ $(28 \%), n=16(40 \%)$, and $n=17(12 \%)$. In addition, it was assumed in the calculations that the numbers of actual and expected zygotes with $2 n=32$ 
chromosomes were the same. Further, on the basis of the observations made (12), there was reason to assume that the formation of the female gametes is in principle similar to that of the male gametes.

It seems apparent that a very stringent elimination of zygotes with hypotetraploid chromosome numbers has taken place. On the other hand, the comparison of the actual and expected groups with hypertetraploid chromosome numbers has revealed a very good agreement between them. The calculated chi square value, 15.3933, for these groups of plants corresponds to the $\mathrm{P}$ value 0.001 . The plant with $2 n=35$ is not one of the expected ones. Its presence may be explained on the basis of an accidental non-disjunction or on the the assumption that not all gamete types were present in the above list. The observed elimination of hypotetraploid zygotes is in good accordance with the statement made by MüNTZING (7) that embryos of hypotetraploid individuals in the progeny of induced tetraploid rye are more defective than embryos of hypertetraploid individuals.

As mentioned above, several characteristics of the plants investigated were recorded at intervals during the whole growth of the material from small seedling plants to full maturity. A clear segregation of many characteristics was observed in the $\mathrm{C}_{2}$ generation. This was to be expected because the diploid parent clone was apparently to a considerable extent heterozygous (12). The segregation was visible among the even tetraploids as well as among the hypo- and hyperploid off-types. Owing to the segregation, comparison of single individuals did not give any reliable results. It was possible to determine the effect of aneuploidy only by comparison of whole groups.

Table 2. Mean height $(\mathrm{cm}$.) of plants in different chromosome classes at different dates of measurement.

\begin{tabular}{rrrrrrr}
\hline Date of measurement & $2 n=32$ & $2 n=31$ & $2 n=33$ & $2 n=34$ & $2 n=16$ \\
\hline June 15,1947 & 11.4 & 11.6 & 10.9 & 10.6 & 14.0 \\
Sept. 23,1948 & 37.6 & 40.4 & 33.3 & 30.5 & 47.7 \\
May & 20,1949 & 56.0 & 56.8 & 50.6 & 43.6 & 55.3 \\
Sept. 19,1950 & 74.4 & 78.9 & 72.0 & 68.4 & 83.0 \\
\hline
\end{tabular}

There were a considerable number of characters in regard to which no visible differences were observed between tetraploids and the chromosome number variants. Characters belonging to this category were colour, texture and general shape of the leaf, mode of growth, length of internodes, and number of flowers per raceme.

The rate of growth is one of the characters apt to exhibit differences between even and aneuploid chromosome types. The average heights at different dates of measurement are presented in table 2. A phenomenon characteristic of colchicineinduced tetraploids in $R$. nigrum is immediately noted: their total growth is appreciably less than that of the diploids (12). In addition, it is seen that the heights in the hypoploid 31-chromosome type are greater than those of the even tetraploids. The differences between the mean heights of even tetraploids and different groups of chromosome number variants are presented in table 3 . 
Table 3. Differences in mean heights of even tetraploids and different aneuploid types, $t$ values, and the significance of differences.

\begin{tabular}{|c|c|c|c|c|c|c|c|c|c|}
\hline $\begin{array}{c}\text { Date of meas- } \\
\text { urement }\end{array}$ & $\begin{array}{c}\text { Diff. (cm.) } \\
32-33\end{array}$ & t value & $\mathrm{P}$ & $\begin{array}{c}\text { Diff. (cm.) } \\
32-34\end{array}$ & t value & $\mathrm{P}$ & $\begin{array}{c}\text { Diff. (cm.) } \\
31-32\end{array}$ & $\mathrm{t}$ value \\
\hline June 15, 1947 & 0.5 & 0.56 & 0.6 & 0.8 & 0.77 & 0.4 & 0.2 & 0.22 & 0.8 \\
Sept. 23, 1947 & 4.3 & 1.88 & $0.05 *$ & 7.1 & 2.57 & $0.01 * *$ & 2.8 & 1.54 & 0.1 \\
May 20, 1949 & 5.4 & 1.55 & 0.1 & 12.4 & 3.01 & $0.001 * * *$ & 0.8 & 0.27 & 0.8 \\
Sept. 19, 1950 & 2.4 & 0.37 & 0.7 & 6.0 & 0.78 & 0.4 & 4.5 & 0.74 & 0.4
\end{tabular}

Table 3 shows that there is no significant difference between the growth rates of even tetraploids and the 31-chromosome type. The growth of the hyperploid 33-chromosome type is slightly weaker than that of the even tetraploid. The excess of two chromosomes in the 34-chromosome class has caused a more pronounced retardation of growth. Further it is seen that the observed differences in growth rate are restricted to the active growth period of the plants. There are no significant differences between heights at the early stages of development (first measurement). On the other hand, differences in height have disappeared at maturity (last measurement).

Table 4 presents the records relating to the beginning of flowering in plants belonging to the different chromosome classes.

Table 4. Relative numbers of flowering and non-flowering plants at different dates of recording.

\begin{tabular}{|c|c|c|c|c|c|c|c|c|}
\hline \multirow{2}{*}{$\begin{array}{l}\text { Date of } \\
\text { recording }\end{array}$} & \multicolumn{2}{|c|}{$2 n=32$} & \multicolumn{2}{|c|}{$2 n=31$} & \multicolumn{2}{|c|}{$2 n=33$} & \multicolumn{2}{|c|}{$2 n=34$} \\
\hline & $\begin{array}{c}\% \\
\text { flowering }\end{array}$ & $\begin{array}{l}\% \text { non- } \\
\text { flowering }\end{array}$ & $\begin{array}{c}\% \\
\text { flowering }\end{array}$ & $\begin{array}{l}\% \text { non- } \\
\text { flowering }\end{array}$ & $\begin{array}{c}\% \\
\text { flowering }\end{array}$ & $\begin{array}{l}\% \text { non- } \\
\text { flowering }\end{array}$ & $\begin{array}{c}\% \\
\text { flowering }\end{array}$ & $\begin{array}{l}\% \text { non- } \\
\text { flowering }\end{array}$ \\
\hline May 14,1948 & 15.7 & 84.3 & 16.7 & 83.3 & 5.6 & 94.4 & 8.3 & 91.7 \\
\hline ) 19,1949 & 53.7 & 46.3 & 68.7 & 31.3 & 63.2 & 36.8 & 18.2 & 81.8 \\
\hline ) 19,1950 & 68.7 & 31.3 & 72.2 & 27.8 & 73.7 & 26.3 & 50.0 & 50.0 \\
\hline
\end{tabular}

We see from table 4 that there is no retardation in the beginning of flowering in the 31-chromosome class when compared with the even tetraploids. On the other hand, the tendency to begin flowering later is clearly distinguishable in the groups of hypertetraploid plants. In the 33-chromosome class the increase of late flowering is noted only in young plants. The observed difference disappears completely in older plants. The records for the 34-chromosome group show that the tendency to flower late is pronounced and persists until plants have attained maturity. In this class plants were observed which remained totally sterile. It may be mentioned that there is no clear difference in the beginning of flowering when diploid and tetraploid black currants are compared.

The beginning of growth, i.e., the opening of leaves in spring, clearly occurs earlier in tetraploids than in diploids (12). The defoliation in fall, however, occurs in general somewhat later in diploids, and the length of the growth period thus remains about the same. There is, nevertheless, considerable individual variation 
in the length of growth periods among tetraploid types. In table 5 are given the relative numbers of different growth period types in the different chromosome classes.

Table 5. Relative numbers of different growth period types in different chromosome classes.

\begin{tabular}{lrrrr}
\hline Type of growth period & $2 n=32$ & $2 n=31$ & $2 n=33$ & $2 n=34$ \\
\hline normal & $90.2 \%$ & $89.5 \%$ & $70.6 \%$ & $72.7 \%$ \\
long & $2.4 \%$ & $10.5 \%$ & $11.8 \%$ & $18.2 \%$ \\
short & $7.4 \%$ & - & $17.6 \%$ & $9.1 \%$ \\
\hline
\end{tabular}

From the data presented it is seen that the even tetraploids as well as the 31chromosome group are very similar when the frequency of normal and atypical growth periods are compared with each other. In both groups of hypertetraploids a clear drop is observed in the proportion of normal growth periods in favour of the exceptional, short and long, ones.

\section{Discussion}

The effect of aneuploidy upon the $\mathrm{C}_{2}$ generation derived from an induced autotetraploid $R$. nigrum is, according to expectation, slight. It can be ascertained only statistically, and even then as an increase in the number of individuals which show deviations in certain characters. The changes observed do not concern distinct morphological characteristics, but only some developmental processes that are apparently determined by polygenic systems.

It seems evident on the basis of the observations made that the effect of hypotetraploidy is less pronounced than that of hypertetraploidy, and that the effect of two chromosomes in excess is greater than the effect of one extra chromosome. This type of effect is contrary to the observations presented by YARNeLL (15) on $3 n-1$ and $3 n+1$ types in Fragaria. The observed effect of extra chromosomes, i.e., tendency to retard growth, to retard flowering, and to effect abnormal growth periods, are characteristics which, so far as it is possible to judge correctly, are apt to diminish the viability of the individuals in the population. The effect of one extra chromosome however, is, evidently of very little practical importance.

There are in the literature only a few observations concerning the viability of trisomic and tetrasomic types derived from tetraploids. Clausen and GoodspEED (4) did not establish any change in viability in the trisomics of Nicotiana tabacum. According to Müntzing (6), the relative vigour of plants decreases with departure from even ploidy in Dactylis glomerata.

An interesting phenomenon is the undiminished vigour of $4 x-1$ types in $R$. nigrum. An increase in vigour is actually observed in some respects, for example, in growth rate. This may perhaps be explained by an approach of the plants to 
the diploid state by the loss of one chromosome of the four present. In general the monosomic types seem to show somewhat lower vigour than even tetraploids (6), but exceptions may also be found in the literature, e.g., the observations of LAMMERTS (5) on Nicotiana rustica.

It may be mentioned that there is some indirect evidence indicating that the normal chromosome number of $R$. nigrum, $2 n=16$, is not the basic number but corresponds to a tetraploid although it is evidently strongly diploidized (13, 14). The artificial tetraploid would hence represent an octoploid status, at least with respect to some of the genes. This condition would, indeed, lead to a further weakening of the effect of aneuploidy.

The range of viable aneuploids in R. nigrum seems to be rather narrow. As mentioned above, the 30- and 35-chromosome types found were quite weak and died very soon. This does not support the assumption of a low original basic chromosome number in the genus Ribes.

From the viewpoint of practical breeding, owing to their low vigour, the hypertetraploid types do not possess any advantages. The monosomic $4 x-1$ types, on the contrary, may sometimes possess favourable characteristics as compared with even tetraploids. The increased growth rate with the preservation of the basic characteristics of a tetraploid is to be considered an advantage.

\section{Sum $m$ ary}

Morphological and developmental characteristics of a total of 139 even tetraploid $(2 n=32)$, hypo- $(2 n=31)$, and hypertetraploid $(2 n=33,34)$ Ribes nigrum plants derived from colchicine-induced autotetraploid parents have been under observation from the seedling stage to full maturity. The records made have been treated statistically by comparing different chromosome classes with each other, the purpose being to reveal the possible phenotypic effects of aneuploidy upon the species.

It was found that a stringent elimination of hypotetraploid zygotes took place when the progeny studied developed.

The effect of aneuploidy was to be seen only in some developmental characteristics in hypertetraploid chromosome classes. The effect was very slight in the $4 x+1$ types but more pronounced in the $4 x+2$ group. The effect was observed as a tendency to a lower growth rate during the active growth period of the plants. Furthermore, a tendency to a retardation of the beginning of flowering was observed, as well as an increased proportion of exceptional, long and short, growth periods in hypertetraploid populations.

The vigour of monoploid $4 x-1$ types was fully maintained, and even an increase in growth rate as compared with that of even tetraploids was observed. 


\title{
LITERATURE
}

(1) Blakeslee, A. F. 1930. Extra chromosomes, a source of variation in the Jimson weed. Annual Rep. of the Smithsonian Inst., p. 431-450.

(2) —- 1937. Studies in the behaviour of chromosomes. U. S. Dept. Agr. Yearbook, 1605, p. $1-35$.

(3) Clausen, R. E. and D. R. Cameron, 1944. Inheritance in Nicotiana tabacum XVIII. Monosomic analysis. Genetics, 29, p. $447-477$.

(4) - - and T. H. GoodspeEd, 1924. Inheritance in Nicotiana tabacum IV. The trisomic character nenlarged». Ibid., 9, p. 181-197.

(5) Lammerts, W. E. 1932. Inheritance of monosomics in Nicotiana rustica. Ibid., 17, p. 689-696.

(6) Müntzing, A. 1937. The effects of chromosomal variation in Dactylis. Hereditas, 23, p. 113-235.

(7) —- 1943. Aneuploidy and seed shrivelling in tetraploid rye. Ibid., 29, p. 65-75.

(8) SeArs, E. R. 1944. Cytogenetic studies with polyploid species of wheat II. Additional chromosomal aberrations in Triticum vulgare. Genetics, 29, p. 232-246.

(9) Sмith, H. H. 1943. Studies on induced heteroploids of Nicotiana. Amer. Jour. Bot., 30, p. $121-130$.

(10) Stebins, G. L., Jr., 1947. Types of polyploids: their classification and significance. Adv. in Genetics, 1, p. 403-429.

(11) - - 1950. Variation and evolution in plants. Columbia Univ. Press, New York.

(12) Vaarama, A. 1947. Morphological and cytological studies on colchicine-induced tetraploid Ribes nigrum. Acta Agr. Fenn., 67, n:o 2, 55-92.

(13) —- 1948. Cryptic polyploidy and variation of chromosome number in Ribes nigrum. Nature, 162 , p. 782 .

(14) —- 1949. Spindle abnormalities and variation in chromosome number in Ribes nigrum. Hereditas, 35 , p. $136-162$.

(15) Yarnell, S. H. 1931. A study of certain polyploid and aneuploid forms in Fragaria. Genetics, 16 , p. $455-489$.

SEL OST U S :

\section{ANEUPLOIDIAN VAIKUTUS AUTOTETRAPLOIDIN MUSTAHERUKAN JÄLKELÄISPOLVEN OMINAISUUKSIIN}

\author{
Antero VaArama
}

\section{Maatalouskoelaitoksen puutarhaosasto, Piikkiö}

Kolkisiinikäsittelyllä aikaansaadun neliannoksisen mustaherukan jälkeläispolvessa tavataan osassa yksilöitä tasaisen neliannoksisen, tetraploidisen, kromosomiluvun, $2 \mathrm{n}=32$, poikkeamia. Näissä joko yksi kromosomi puuttuu tai kromosomeja on joko yksi tai kaksi normaalia enemmän. Tällaisten, aneuploidisten, yksilöiden useita ominaisuuksia on havainnoitu taimiasteelta täysikasvuisuuteen saakka ja kromosomiluvuiltaan erilaisista yksilöryhmistä mitattuja ominaisuuksia vertailtu tilastollisesti toisiinsa.

Aneuploidian vaikutus on odotusten mukaisesti heikko autotetraploidisissa kasveissa. Se on lähinnä todettavissa eräissä suhteissa poikkeavien yksilöiden suhteellisena lisäytymisenä aneuploidien ryhmissä. Yhden kromosomin puuttuminen ei aiheuta elinkykyisyyden alenemista. Päinvastoin tämä ryhmä ylittää pituuskasvuunsa nähden normaalit tetraploidiset yksilöt läheten kaksiannoksisia, diploidisia, muotoja. Ylimääräisillä kromosomeilla sensijaan on taipumus alentaa jonkin verran yksilöiden elinkykyä. Kahden ylimääräisen kromosomin vaikutus on voimakkaampi kuin yhden. Tämä todetaan selvästi hidaskasvuisuuden ja pitentyneen kukkimisen alkamisiän lisääntymisenä niissä populaatioissa, joissa ylimääräisiä kromosomeja on tavattu. 